\title{
The Sentimentalization of American Political Rhetoric
}

Bruce E. Gronbeck

Poroi, 4, 1, March, 2005

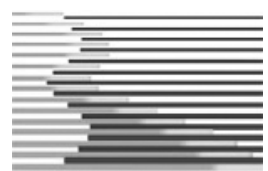

Project On Rhetoric Of Inquiry

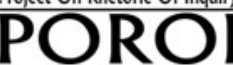

http://ir.uiowa.edu/poroi

1 If we are to believe Cicero's reports in his Brutus, sentimental discourses were a staple of Roman legal and legislative proceedings. For example, he praised Servius Sulpicius Galba as an orator "who inflames the court," thus accomplishing "far more than the one who merely instructs it." When charged with massacring Lusitanians, "with tears in his eyes [Galba] commended to [the Roman people's] protection his own children as well as the young son of Gaius Gallus. The presence of this orphan and his childish weeping excited great compassion" (xxii, 89-90), and of course Galba was acquitted. Even casual readers of the Iliad discover speeches full of invective (Achilles' rage), patriotic encomium (Hector's battle cry), and sententious disquisitions on the nature of life, love, death, and sociality (Achilles' vision of Patroclus). These can unify a people around sentiments of duty, patriotism, fidelity, and amity (books 1, 12, and 23).

2 In spite of such examples of emotional advocacy and bonding, pathos and the sentimental appeal have regularly come under attack in the West. Plato's rants on poetic delirium in the Ion and his authorship of Callicles' cynical discussion of public emotion and politics in the Gorgias are undisguised assaults on the force of feelings in public places. Plato was convinced that episteme inevitably erodes in the discourses of doxa. The Church Fathers Tertullian in particular - believed with equal firmness that desire releases from the bondage of proper personal control all manner of licentious behavior (Sider 1971). Thence it undermines divine authority over human action. Thus, perhaps oddly, pathos always has been recognized as a mode of proof ( pistis) in the rhetorical canon; yet it always is to be in some way circumscribed, tempered, or even imprisoned.

3 To address all emotional appeals in public rhetoric could rapidly become an exercise in hyper-abstraction. Even sentimentality, as only one strain of emotional discourse, is too multidimensional for a single analysis. So we focus here on the use of sentimental discourse to rouse, intensify, then celebrate political action and group membership. Yet the larger aim remains to see how we 
ultimately might analyze the places of pathos in rhetoric.

In our time, the central medium of sentimental politics is television. When a reader has not - literally - seen some of the televisual events noted here, the analysis of sentimentalization could lose its evocativeness. Not to worry, though, for new exemplars are no further away than the next televised speech about God, motherhood, and country.

The modern case for sentimentalizing moral action in public emerges in the Scottish Enlightenment, and it becomes particularly clear in Adam Smith. So we turn next to his breathtakingly compressed talk about sentiment, vision, and action, and some positive and negative assessments of sentimental words and pictures. Then we examine three prominent forms of sentimental argument in present politics: patriotic calls to party support, personalized appeals to political action, and collective celebrations of political membership. To conclude, we return to the larger horizons of political practice, theory, and ethics for pathos in our rhetoric.

\section{Sentimentalizing Moral Action}

6 Greek philosophy and Christian theology mostly condemned sentimentality. From the posters for World War I to the film genres throughout the twentieth century, visual rhetoric has attracted similar deprecation. Some blasted fallacies of propaganda (Lasswell 1971). Others knew that Leni Riefenstahl's Triumph of the Will (1935) would make Nazis of us all. Pundits on both sides warned that Michael Moore's Fahrenheit 911 could turn the 2004 presidential election irrational and immoral. There always has been a tone of elitism in such talk: hoi polloi are too weak-minded to resist visual rhetoric (even if we pundits can see it for what it is). And then, when pictures are added to sentimental prose, as we shall see, negative judgments reach new horizons and heights.

7 Not until Adam Smith's treatise on The Theory of Moral Sentiments (1759) were the emotional and the sentimental framed theoretically as proper and effective modes of rhetoric, capable of powerful deployment in the pursuit of moral rectitude and political action. ${ }^{1}$ This is not the place for an enlarged examination of the eighteenth-century discussions of relationships between sentiments and morality. Suffice it to say that the idea of sympathy became a technical, philosophically sophisticated, 
notion. Still there is a claim to be made for Smith's originary uniqueness in basing his theory of sentiments on sympathy.

8 Before Smith, Anthony Ashley Cooper, Third Earl of Shaftesbury, had explored sympathy as a binding, socially powerful force in collectivities. Human collectivities arise, he believed, from a "natural" herding and associative principle - a shared sense of preservation. Polities hold together through shared "succour," which could lead to either common affection (if heroic) or division (if factious). ${ }^{2}$

9 A second tack was taken by David Hume. While his Enquiries Concerning Human Understanding and Concerning the Principles of Morals (1975a) discusses sympathy in social terms not unlike Shaftebury's, Hume's earlier Treatise of Human Nature (1975b) offers a psycho-epistemological approach to the idea. It features the paradox of how it is that we can react to another's fortune (or misfortune) through both sympathy and envy - or sympathy and enjoyment (Deleuze 1991). Hume's principal tactic in handling the paradox was through what Baier (1991, p. 147) identifies as "the principle of comparison" - a version of a cognitive process whereby "lively ideas" about self are set against each other. In the Treatise, then, Hume probed the mind's involvement with an outside (here social) world.

10 The uniqueness - and utility - of Smith's approach to sympathy is that it is neither grossly social nor minutely psychoepistemological. It is based on what Nussbaum (1995, pp. 72ff.) identifies as a theory of the "judicious spectator," an idea developed further here. Such a theory does not account for sociality, but neither does it depend on comparisons between the spectator's own situation and that of another. Smith's doctrine of sympathy involves not coming to know but coming to judge. Hence it is not just associative (Shaftebury) or comparative (Hume) but evaluative. It involves a kind of personal identification but also an essentially external assessment.

11 The Theory of Moral Sentiments opens with Smith's famous statement about human sympathy: "How selfish soever man may be supposed, there are evidently some principles in his nature, which interest him in the fortune of others, and render their happiness necessary to him, though he derives nothing from it except the pleasure of seeing it" (p. 9). For Smith, sympathy operates directly, much like sympathetic or harmonic vibration, without the interposition of systematic cognition: "Whatever is the 
passion which arises from any object in the person principally concerned, an analogous emotion springs up, at the thought of his situation, in the breast of every attentive spectator" (p. 10).

12 Sympathy, therefore, does not arise so much from the view of the passion, as from that of the situation which excites it. We sometimes feel for another, a passion of which he himself seems to be altogether incapable; because, when we put ourselves in his case, that passion arises in our breast from the imagination, though it does not in his from the reality. We blush for the imprudence and rudeness of another, though he himself appears to have no sense of the impropriety of his own behaviour; because we cannot help feeling with what confusion we ourselves should be covered, had we behaved in so absurd a manner (p. 12).

13 Analogous emotions come to our thoughts because people project themselves psychologically into the situations where they see others.

14 Smith explained that mutual sympathy - the experiencing of joy and grief jointly with others - enlivens our emotional experiences. It adds collective joy to our pleasant experiences, and it allows the sympathy of others to help us alleviate our personal sense of tragedy (I.i.chapter 2). By Part III of his treatise, Smith argued further that sympathy grounds judgments of conduct by ourselves or others, since these mirror each other in our comparisons (especially pp. 109-110). ${ }^{3}$

15 Such mirroring does not turn two persons into one; separate identities are maintained. Thus cognitive processes are central to Smith's understanding of sympathy. He wrote of the "judicious spectator" in the language of cognitive processing: "the spectator must ... endeavor, as much as he can, to put himself in the situation of the other, and to bring home to himself every little circumstance of distress which can possibly occur to the sufferer. He must adopt the whole case of his companion with all its minutest incidents; and strive to render as perfect as possible, that imaginary change of situation upon which his sympathy is founded" (p. 21).

16 Martha Nussbaum continues Smith's line of thought as well as his words: "both empathetic participation and external assessment are crucial in determining the degree of compassion it is rational to have for the person: The compassion of the spectator must arise altogether from the consideration of what he himself would feel if 
he was reduced to the same unhappy situation, and, what is perhaps impossible, was at the same time able to regard it with his present reason and judgment'”' (1995 pp. 73-74; Smith 1759, p. 12). For Smith and Nussbaum, both empathy and rational judgment can coexist phenomenologically (see Smith's examples, p. 16).

17 Throughout the treatise, Smith's imagery for sympathy is visual: seeing, mirroring, reflecting, spectating, depicting events in fact or imagination. When talking about regulating our own conduct in the presence of others, Smith said, "We suppose ourselves the spectators of our own behaviour, and endeavour to imagine what effect it would, in this light, produce upon us. This is the only looking-glass by which we can, in some measure, with the eyes of other people, scrutinize the propriety of our own conduct. If in this view it pleases us, we are tolerably satisfied" (p. 112). His is a language of spectators, images, looking-glasses, eyes, and views.

18 For Smith, such self-examination produces a divided persona. "In all such cases, I divide myself, as it were, into two persons." He argued "that I, the examiner and judge, represent a different character from that other I, the person whose conduct is examined into and judged of" (p. 113). Smith contrasted these as the spectator and the agent. Such a divided self resurfaces in George Herbert Mead's (1934) distinction between the acting "I" and the judging "me."

19 And so in the late eighteenth century, there appeared a theory of moral and political action based on an emotion- and visioncentered theory of sociality. Smith's titular term, "moral sentiment," framed an entrance into non-logical - though certainly not non-rational - modes of collective decision making. The next century saw continued exploration of sentimentality as a basis of ethics and politics in the loosely moralistic popular literature of the West (Black 1978). Verbal depiction of social-political situations as well as of morally sensitive behavior within such situations was central to the English artis poetica et rhetorica (Osborn 1982). The same held for the bombastic, spread-eagle oratory prominent in American commemorative politics (Weaver 1953). But once the techniques of verbal depiction at the heart of the sentimental style were supplemented by the mechanically reproduced visual images and sounds of twentieth-century media, concern for the irresistible power of imaged sentimentality became even greater.

20 That new twentieth-century professional, the publicist, often 
followed the advice of AT\&T Director of Public Relations William P. Banning: if the publicist "will remember that an appeal to the heart, to the sentiments, is more resultful than one based on logic, he has the beginnings of a good technique" (Ewen 1996, p. 194). In the same 1923 speech, he also recommended that the professional should "Think of your whole advertisement as a picture, and I believe you will find the problem of securing an attractive result will be simplified" (p. 195). Banning was echoing the assumptions of social psychologist Harry Overstreet at the New School for Social Research: "words and pictures are tools. They are tools for communicating ideas, stimulating interests, arousing feelings and emotions" (p. 197). In an explanation that parallels Smith's theory of sympathy, Overstreet held that pictures were all-powerful because "The secret of all true persuasion is to induce the person to persuade himself. The chief task of the persuader, therefore, is to induce the experience. The rest will take care of itself" (p. 199; see Sproule 1997, especially chapter 1). Smith treated situational cues in a similar way.

21 In this mode, mechanically reproduced images of society took center stage in western politics. The poster propaganda of World War I (Hardie 1920) joined the photos that filled the newspapers of the time (Gidal 1973). Film newsreels appeared in 1911, and sound newsreels in 1927 (Fielding 1972). The first campaign film was made for Calvin Coolidge in 1924 (Morreale 1993). Socialaction documentary films became popular for Americans and Britons in the 1930s (MacCann 1973). By 1952, political programming and advertising were becoming familiar on American television (Becker 1979).

\section{Fearing Sentimental Images}

22 Sentimentalized visual discourses have invaded social and political relationships - particularly the worlds of public relations, product and political advertising, political commemorative spectacle, and political campaigning. This has been highly controversial. When Edwin Black ruminated on the rise of the sentimental style in nineteenth-century literature and oratory, he was repelled by what he saw: "I believe it useful to view the sentimental style as the manifestation of a disposition to subordinate all values to aesthetic values in order, essentially, to escape the burden of moral responsibility" (1978, p. 83). The heir to that style in our time, Black suggested, is television:

23 Television news presents a veritable plethora of moral concern, 
and we viewers are invited to live lives of unremitting social guilt. But even when it has horrors to convey, television orders, edits, and comments upon its photography with strict attention to the dramaturgic expectations of its audience. Thus, television reportage works, as the sentimental style did, to render public issues aesthetically palatable (p. 84).

24 Black proceeds to argue that there are affirmative aspects of sentimentality, because he believes it always is a precursor to a new sensibility - a new "style and form of consciousness" (p. 85). The compliment is backhanded, though, still distrustful of feelingbased action.

25 The connection of visualization to political sentimentalization has been complicated in our time by many accounts. Guy Debord (1983) viewed the spectacle as the West's means of constructing social relationships. Martin J ay (1994) tells of Europe's epistemological surrender to the ocular-centric from the preSocratics forward. Paul Messaris (1994) provides a scientistic grounding of collective cognition in visual literacy, while J ohn Hartley (1992) constructs links between visual readership and political citizenship. Barbara Stafford's manifesto on "the knowingness of visual communication" attacks "the conjunction of psyche with logos" as challenges to those who have equated verbal language and knowing (1996, pp. 5 and 6). Innumerable postmodern accounts of life stress the (visual) surfaces of indeterminate feelings and cognitions (Lyotard 1984; Baudrillard 1983, 1988). Any such list can only be suggestive of the range of discourses that impinge upon the intersecting topics of visual discourse, sentimentality, and social-political action.

26 To make this more concrete, consider one of the unhappy accounts of emotionalism. In Seducing America: How Television Charms the Modern Voter (1999), Roderick Hart argues that "Television . . . has ushered in a Second Renaissance, substituting mass emotion for mass subservience to the church in Rome. Television has also ushered in a Second Enlightenment, requesting that the brain, too, serve the dictates of the heart" (p. 153). In particular, says Hart, television makes five unfortunate feelings central to American voters:

1. detachment: Television so involves us in the intimacies of personality politics that we end up hypersensitized to political individuals and thus detached from political institutions and actions; 
2. ignorance: Political information generated by $24 / 7$ news overwhelms and shuts us down; it leaves us feeling at sea without any actual political knowledge with which to make judgments;

3. obsolescence: The flood of televised political information produces a sense of "nowness," an "endless string of facts and anticipations" (p. 157), that can make yesterday's information old and inadequate for handling tomorrow's problems, which in turn get remade by tomorrow's facts and anticipations;

4. inertness: Because "television makes watching and doing the same thing" (p. 158), political lethargy results from consuming televisual political discourses;

5. impotence: "Because of television," concludes Hart, "we now see all and know all. When people like ourselves appear on television, acting as we might act, we seem to do all as well. Television takes viewers into the vestibules of power in Washington, into a thousand boudoirs. Why would people who see so much need to act at all? That, I think, is the question of our age" (p. 160).

To Hart, these five states of feeling are products of the seeming intimacy, the pseudo-sense of personal involvement in politics, produced by the most widely used visual technology in the country - along with the culture-sensitive news practices developed for its public use. The five converge to severely strain the efforts of goodgovernment people to rekindle an American spirit of political participation through calls to duty, community, and hope (p. 172).

27 In many ways, Hart is correct. The sentimentalization of politics can produce a false sense of intimacy. In the 1992 president campaign, Bill Clinton sat on a couch with his wife while they talked to us on 60 Minutes about his relationships with other women and the details of their marriage. We were with them, and we felt their pain. To watch the primetime hours of network coverage for a national convention, Republican or Democratic, can make us feel we were there, personally guided through the events by anchors, reporters, and politicians. Could Hart be correct about the sentimentalizing of politics as the engine of political disengagement in our time?

\section{Defending Sentimental Images}

28 Sometimes we might be victimized as citizens by experiences of 
pseudo-intimacy with politicians and pseudo-involvement in politics. Nonetheless we also can find good, civically positive uses of sentimentalization in the visual politics of our time. In commenting in his famous "Conciliation with America" on politicization in the American colonies, Edmund Burke argued in 1775 that "close affection" provided the colonists with "ties which, though light as air, are as strong as links of iron" (1963, p. 290). "Affection" to Burke is made "from kindred blood, from similar privileges, and equal protection." So long as affection is maintained, he argued, "they will cling and grapple to you, and no force under heaven will be of power to tear them from their allegiance." If affection is dissolved, "the cement is gone; the cohesion is loosened; and every thing hastens to decay and dissolution." Burke's doctrine here is closer to Shafesbury than Smith, though Burke undoubtedly knew the works of both, and even reviewed Smith's work in his major publication series, the Annual Register. All three saw that sentimentalization can be essential for creating and maintaining political identity and can provide motivational grounds for political action.

29 An article is too short for an adequate theoretical account of sentimentalization as a basis for political identity and action. Here I review examples of campaign discourse that emphasize sentimentality. I draw them principally from political conventions and campaign advertisements, two of the most heavily viewed kinds of political television. I sort the examples into a taxonomy that more or less rationalizes the appeals by hypothesizing why they do worthy political work. Next I examine in more detail a particularly interesting example of sentimentalized politics. Then I conclude with comments on the practice, theory, and ethics of visual culture in politics. The goal is to suggest how imaged sentimentalization can contribute to citizen engagement.

30 Yes, sentimentalization can function in highly negative ways for televisual discourse in politics. Notorious examples include the socalled "Willie Horton" and "revolving door" ads in 1988 (J amieson 1992; Miller 1994) and Patrick Buchanan's savaging of the "two Clintons" in his 1992 address to the Republican National Convention. Emotional tirades can be destructive, even in political campaigns. Yet there are constructive, positive employments of emotional messages. They can do important political work that more enlightened appeals to empirical generalizations or tabulated data cannot. Let us look at examples of (1) patriotic appeals, (2) personalized politics, and (3) party or other collective celebrations. 


\section{Patriotic Calls to Party}

31 Political parties must recruit members. Then they must engage discourses that reinforce party attractions and call wayward members back to active duty. Reinforcement discourses can weave together many techniques, but sentimentalization is often the foundation.

32 Take Aretha Franklin's performance of the national anthem for the Democratic National Convention in 1992. She opened up the text by turning "The Star Spangled Banner" into soul music. In the blues tradition, her riffs echoed both tribulation and triumph. A Baptist choir accompanied her, adding vocally to her theatrics. Cameras cut between the stage scene and (especially the AfricanAmerican) audience members, to show their responses ranging from tearful head-nodding to joyful applause. All this interlaced the anthem of collective American identity with more personalized testaments to individuals' feelings about that identity and their membership in the Democratic Party.

33 Calls to return to party membership take other approaches brimming with sentiment. In 1992, the Republicans used Louis Armstrong's "It's a Wonderful World" with a film of sentimental images. It is heavy on happy children of varied ethnic backgrounds; it includes the young and middle-aged along with elderly adults living the good life. It shows diverse families hugging, praying and worshipping, playing sports and family games, and greeting each other warmly. The "colors of the rainbow" celebrated in Armstrong's moralistic tune are illustrated iconically, serving as metaphors for the presumed inclusivity and cohesiveness of the GOP. (Because the convention had opened with hatchet speeches from the two Pats, Robertson and Buchanan, this film also opened up the agenda narrowed by these speakers for the Christian Coalition's morality planks and the Buchanan Brigade's jingoism.)

34 Four years earlier, the Republicans had aired an ad late in the campaign that began and ended with candidate Bush holding a granddaughter. It intercut shots of mass adoration for Bush (or at least his candidacy) with the Bush family barbequing together and Bush pledges to foster a "kinder, gentler nation" by listening to the voices of the "quiet people" who "moved" him. Such campaign discourses use sympathetic appeals in the way that Smith suggested: by allowing viewers to project themselves into situations where they can celebrate the joy of others and the 
comradeship of group identity in reasonable ways. The pictures of Bush and his grandchildren were hardly capable of converting Democrats to GOP voting lists; rather, they employed a familial structure, metaphor, within which to live as a Republican.

\section{Personalized Politics}

35 A sentimental call to return home is not enough, however, to produce political action. In the age of television, the personalized, individuated narrative works synecdochally to materialize political motivation and action. Television is the show-and-tell machine. It is the up-close-and-personal vehicle that offers us individuals who can embody the issues addressed by political platforms. By 1996, both parties were filling their conventions with parades of persons standing for causes.

36 That year, the Democratic National Convention rolled out Christopher Reeve on "American Hero Night." This was his first major public appearance following his paralysis. He spoke of family values and the political family that would join him to fight not only for research on spinal-chord injuries but also for helping all citizens without support. His appeal for party dedication to all in need was empowered emotionally by sights of his sheer, if awkward, physical presence: laid back in a head-locking, bodycradling power chair. The whole speech was phrased in short phonetic strings because of his mechanically augmented breathing, and his soft voice added to the sentimental appeal. His mechanized walk at the 2000 Democratic National Convention, along with the same message, was still another synecdoche for the same political commitments.

37 Perhaps even more dramatic and equally sentimental was AIDS activist Mary Fisher's appearance on the GOP stage that year with a twelve-year-old African American girl. Heideia had been an AIDS baby, and she read a poem about her ambition to be anything she wanted. Fisher added that, when AIDS "has its way with me," her children will belong to the community.

38 Yet the highlight of appeals to personalized sympathy at the 1996 conventions was the seven-minute, breath-by-breath description from Vice President Al Gore of his sister Nancy's death from lung cancer. On the big screen, the Democratic Party and nationwide television audiences saw Gore narrate a story of regret, sorrow, then anger at the tobacco companies. The party audience was stunned into silence as Gore gulped for air, fought off emotional 
breakups, and allowed Nancy's death to turn him into an instrument of political wrath. The cutaway shots of delegates paralleled the shots of Gore, as television viewers saw concern evolve into tears then an outpouring of support for the David ready to take on the Goliaths of corporate tobaccodom.

39 Ironically (or strategically?) Gore began the speech by poking fun at his own rational stiffness. He asked the audience if they wanted to see him do the Macarena. As it shouted encouragement, he stood unmoving then said, "Do you want to see me do it again?" The contrast between this static opening and the animated story of Nancy was breathtaking.

\section{Collective Celebrations}

40 Party membership and group action can and perhaps should culminate in celebration of identities well worn and jobs well done. The Republican Party staged the first great balloon drop on the final night of its 1932 convention around the theme "Press on, Hoover." It offered the newsreel audiences flag-waving, streamercovered delegates, African American as well as white. At least since then, party celebrations have pitched the joy of belonging to a spectatorial public. The 1984 GOP final night featured clowns, Uncle Sam on stilts, jugglers, and all manner of other carnivalesque activity. The 1992 Democratic National Convention reunited the renowned rock group, Fleetwood Mac, to play its great hit that had become the Clinton theme song: "Don't Stop Thinking About Tomorrow."

41 Four years later, the Democrats managed to drop what had to have been the greatest volume of balloons as well as multi-colored mylar pieces ever hoisted to a ceiling. Through the hall blared songs about utopian life and labor union solidarity to underscore the scene. The GOP in 1996 even brought out its "Singing Senators." Led by Senate majority leader Trent Lott, they sang a patriotic medley that Lott assured everyone illustrated party unity. They followed this with an ill-advised (off-key) version of "Elmira" in honor of "the next First Lady," Elizabeth Dole. The revelry filled the front rows with a full-fledged sign corps to provide camera shots with poster-board themes and heroic names. Floor demonstrations, outrageous costumes, films, light shows, orchestras and bands: celebratory spectacles become, not just contexts for political activity, but self-confirming rituals for declaring prideful identity and rewarding action. 


\section{A Purple Heart to Share}

42 A good case for close examination comes from the 1992 presidential campaign of Ross Perot. Its late ads were simple: a colored background with some sort of figure on it, soft music, a warm-voiced narrator, and his words scrolling up the screen. The most sentimental spot shows a Purple Heart medal, awarded for wounds in battle. The background is military camouflage for slow panning of the stern visage of George Washington within the gold outline of the heart. As a lone trumpet plays a mournful tune, a poem-like letter scrolls up the screen. It is read with raw emotion, presumably by its writer:

Dear Ross,

I was awarded the Purple Heart for wounds received during a Vietnam ambush. Over the years, its value to me has grown significantly. And, like my family, it is priceless.

I would be honored if you would accept the loan of my Purple Heart

to keep with you

throughout the campaign.

I believe that it can serve as a compelling reminder that the hard battle ahead can, and must, be won.

Let it also remind you of the army of ordinary citizens that has mustered to your call and looks to you to stop the hemorrhaging of the American spirit.

And to restore honesty, integrity and responsibility to our government.

Like you, I firmly believe that if we stand united we will win. 


\section{Good luck, Ross, \\ Dennis Skrivin \\ Wilmington, Delaware}

The first stanza explains the ad's premise, while introducing the idea of 'priceless value.' In the second, the soldier who has sacrificed his body for his country announces his willingness to part with the marker of his sacrifice, the medal. The third stanza unites battlefield campaigns with political contests by fusing them metaphorically in memory. The fourth stanza identifies military mobilization with political mobilization, using blood imagery to communicate its seriousness. The fifth stanza captures the key value links between military and political campaigns: "honesty, integrity and responsibility." Its reference to restoration is typical of third-party campaigns, which often look to a golden past that must be reassembled in the present. The final stanza contains a turn - "we stand united" - on the Perot party name.

43 The ad is a collective call to patriotic citizenship and even selfsacrifice. It taps multiple sentimentalities. It calls on sympathy for a young man wounded in the war nobody celebrated. It displays a solemn presentation of the marker for that heroism to a new leader for a new era. It casts current politics as warfare, where survival depends on commitments that, by implication, opponents Bush and Clinton do not exhibit. It alludes to standing together late in the campaign as the way to gain what must look like an impossible victory in November. Behind it all looms the orant George Washington: a figure from the depths of American doubt, at Valley Forge (1777), during the Revolutionary War. Echoing music after the climactic battle in such films as Red Badge of Courage (1951) and Glory (1989), the lone trumpet bespeaks respect and resolve, a willingness to give the fullest measure.

44 This video borders on the maudlin, even the histrionic. A faceless soldier gives a personal medal to a candidate who never shouldered a gun. The solemn military icon goes to a rich man trying to wise-crack his way to the presidency. Yet all that is beside the point. The ad seeks to commit citizens to Perot - not for his proposals, not for his oddly populist appeals, not even for the shortcomings of his opponents - but for sentiment: the appeal is to sympathy even as Adam Smith understood it, as grounds for moral (here political) action.

45 The ad's focus of attention is Dennis Shrivin. He is present only in eloquent words, a sincere and tremulous voice, a firm signature. 
He asks citizens to attend to his sacrifices and commitments, to sympathize with him. He challenges them, like Smith's judicious spectators, to alter their political identities and actions, aligning with his devotion to Perot. They are to join "the army of ordinary citizens," personified in Skrivin. Amalgamated in identity and action, they even can celebrate, "if we stand united," a victory in November. All three political functions of sentimental appeal the patriotic call, the personalized politics, the celebration of the collective - occur in this disarmingly simple sixty-second message.

\section{Practice, Theory, and Ethics}

46 Of course, this small video archive has been carefully selected to show some potentially productive arguments from sentiment. Where might these leave us? The question needs answers in practice, theory, and morality.

\section{Practicality}

47 Visual politics running on sentimentalized discourses can perform important, positive functions. Patriotism, personalization, and celebration of the collectivity are reasonable - indeed quasirational - bases for political identity and behavior. The patriotic appeal is the demand of the patria that citizens fulfill their duties to the whole. It is a traditional form of interpellation. Patriotic appeal is almost visceral. It attaches to scenes of celebration and adoration from youth. It grounds itself in feelings of joy and worry, love and devotion. Amor patriae, love of country, is an ambiguous phrase, with patria coming from pater, Latin for father. ${ }^{4}$ Both foundational institutions for western lives - family and country - are captured in patriotic appeal.

48 As a focus on the individual within the whole, personalization, too, is an ancient appeal. Ethos was the concept used to describe the moral condition of the Athenian collectivity and the individual living in it; an ideal ethos is one where individuals personify socioethical standards. Technically, therefore, personalization provides the essential link between individual and public identity or action. It connects individuals to collectivities, and vice versa; it ties our own activities to those deemed sociable by our communities. Virtues and vices appear in the moral frames provided by the images and words of such testifiers as Heideia and Christopher Reeve, the tragic stories of Mary Fisher and Al Gore's sister, or the romantic evocations of America in convention films. This is not the aestheticization that escapes moral burdens, as Black argued; it 
is the personification that rivets individuals to societies and personal actions to collective needs. It works with visualized synecdoches to access the moral bases of larger policy arguments.

49 Then celebration completes or affirms political identity and action. Celebration can be the "Amen!" of the congregation endorsing calls to duty. It can be the applause of the society for action in response to the calls. Collective, mutually reinforcing actions of the kind seen in the somewhat-embarrassing-butenjoyable actions of the Singing Senators or in the group hugs, raised arms, and responsive waves of the 1996 Democratic National Convention draw a circle around the celebrants, framing their celebration on the TV screen. These words, gestures, and rhythms define the in-group. They affirm it by the collective rituals of self-congratulation, group recital, and triumphal music. Communal celebration provides legitimation, blessing individual performances and the institutional values that make the blessings appropriate.

50 There are practical arguments for sentimental images and words. Patriotic hailing, personalized story-telling, and collective celebration can direct reasonable action and legitimate political identity. These considerations, of course, must resurface when we discuss the ethical implications of sentimental appeals.

\section{Theory}

51 But first the theory of sentimentalization deserves attention. Two strains of theoretical inquiry are especially promising. For one thing, we should consider how these discourses work persuasively. Television demands that audiences work across three codes - the literate, the acoustic, and the visual - to construct messages made out of different sign systems (Gronbeck 1995, 1993). Most often, these discourses work evocatively. Especially in the acts of persuasion identified here, political television elicits from viewers the ideational and emotional associations that they make as citizens when presented with specific signs in writing, sound, and imagery. This taps a kind of intertextuality where television draws power from previously experienced works, which it evokes semiotically (Fiske 1989).

52 The GOP film accompanied by “It's a Wonderful World" depends on evoking from its audiences the warmth of familial memories, the social support from shaking a neighbor's hand, the nostalgia of seeing an Amish buggy on a dirt road, the smell of a newborn baby, 
and dozens of other feelings triggered by the visual array of signs comprising that film. The Purple Heart ad is not particularly powerful if its viewer does not know that sort of medal, has never seen a war movie where those who have died for country are recognized by a solitary bugle, or is not aware of American discourses about Vietnam. ${ }^{5}$

53 Persuasion by pathos can put the burden or even the authority for changing minds and acts on the listeners or viewers rather than the originator of the message. This is the genius of evocative approaches to political (or any other kind of) persuasion. Only if viewers feel in themselves resonant responses to Gore's performance of his sister's cancer - only if they experience along with him his portrayal of sorrow, pity, and holy anger - does his speech justify a jihad against Big Tobacco or respect for Gore as a leader.

54 This is the essence of Smith on the judicious spectator. It constructs sentimentality as a proper and useful ground of political identity and moral action; moreover the identity and action motivate themselves through sympathy. Message producers present an array of particular signs that can spur specific echoes or memories - responsive chords, Tony Schwartz (1973) called them - in witnesses who then act on them. The responsibility for identities assumed and actions initiated is the judicious spectator's. Political agency is in the eyes of the beholder, as Overstreet argued eighty years ago.

55 A second set of theoretical interests involve collateral questions. This is not the place for a broad exploration of issues linked to the politics of sentimental images. We do well, though, to notice that related concerns include rhetoric's relationships to hermeneutics, deconstruction, and postmodern thought.

56 Derridean (e.g.,1993) issues of destabilized meaning arise from this essay's examples. What connections of past and present operate when we hear Aretha Franklin's rendition of the "Star Spangled Banner" at one convention and the Singer Senators' "Grand Old Flag" at the other? Likewise the examples are rife with hermeneutic circles, deconstructive discourses, and video collages that call up Lyotard's (1984) discussion of the postmodern condition. When Franklin remakes the national anthem to fit an African-American soul-singer with a back-up Baptist choir, we are experiencing the destruction and reframing of a master narrative. 
57 Recontextualized discourses such as Armstrong's "It's a Wonderful World" and the Singing Senators' version of "Elmira" create subtexts that insist on analysis. In radically personalizing his sister's death, Gore savages the tobacco industry and slights the medical establishment. He implies an irrelevance of modern institutions to postmodern experiences. The structuring absences in Perot's "Purple Heart" ad cry out to be made present, in action as well as commentary. The subversion of linguistic rationality that is so visible in the Armstrong film and the Bush ads bring Baudrillard $(1983,1988)$ to mind. The same goes for the strongly self-reporting language of Gore. There is much to learn in the structuring of desire when Mary Fisher uses an African-American girl and Dennis Skrivin awards Perot a medal for sacrifice.

58 My own work emphasizes rhetoric. For too long, rhetoric has been the hostage of logos. Rhetoricians generally have bought into the hyper-neo-Aristotelian belief that rhetoric ought to produce a largely ratiocinative discursive practice, a counterpart (antistrophê) for dialectic, not poetic (Gronbeck, 1999). Lost for much of the Western history of rhetorical thought has been a serious investigation of relationships among rhetorical discourse and desire, feeling states, and moral sentiments within particular configurations of time and space. In segmenting the grounds for conviction ( pistis) into three separate mechanisms - logos, ethos, and pathos - we have been facile. We have allowed each to become a separate route to public identity and action. With the separation, of course, has come an emphasis on what could then be construed as the reasonable ( logos) or even the moral ( ethos) at the cost of ignoring or denigrating the emotional ( pathos).

59 A consequence of these great sullies and silences across the centuries has been our inability to explain the emotional bases of public action outside of wholly rational or quasi-logical and of alluring characterological frameworks. Even in our time, the emotional has been regarded as grounded in mob psychology, groupthink, or other anti-rational realities and infantile desires to follow power. But emotion might not even be non-rational, let alone anti-rational and infantile; feelings are not somehow automatically blind or thoughtless. Rationalists invoke extreme examples when they associate emotionalism with Hitler, McVeigh and Nichols, the Branch Davidians, or Al Qaeda. The penchant to lump all emotional discourses into barrels of bombast and butchery just makes our troubles worse. To try to excise the emotional in the name of political sanity and moral sanitation is to attempt the impossible while turning away from the humanizing 
capacities of sentiment, sympathy, empathy, or sheer feeling.

60 Rhetoric has room for hermeneutics, deconstruction, and other postmodern discourses. Even when hermeneuts tear meaningmaking away from the present, deconstructionists subvert manifest meanings, or postmodernists play across surfaces, they need not be anti- or counter-rhetorical. Rather we can move with Gaonkar to treat rhetoric as "the foundational discipline ... for the human sciences" (1999, p. 209). Rhetoric is a general theory of discourse but one closely attuned to its situations and users. Its accounts of situated symbol use suit many purposes of hermeneutics, deconstruction, and postmodernism. The stress on situations, on the historical specificity of rhetorical acts, makes rhetoric a general theory of discourse - while most forms of posttalk are not. Cultural theorists, especially when inspired by European traditions, too often settle for ascribing power in general to discourses in general. Rhetorical analysts locate specific powers where they operate in concrete settings of everyday life. Attention to situations lets us understand and assess discrete rhetorical fields or styles in particular discursive circumstances.

61 The need is not for translations of Baudrillard or Bourdieu into some lexicon of enthymemes, dispositional patterns, and schemes. We especially need not turn visual discourses into verbal equivalents, as though a traditional vocabulary of rhetoric can be used to sort visual techniques into the officia rhetoricae. This insults - and destroys - the distinctive richness of visual communication in our time. Because our post-isms are discursive practices, with theories of symbol use constructed for purposes at once intellectual, social, and political, we can learn from them as rhetorical forays into our world (Gronbeck 2005). This seems to me the shared teaching of such critical rhetoricians as McKerrow (1989) and such postmodernists as McGee (1990).

62 General talk about the visual world as mere images or surfaces tells us little about how specific images work in particular contexts. To dismiss the close of Clinton's 1996 convention as a "deification of technology" (Postman 1992, p. 71) is to say little about its effects on viewers. To argue that "spectacular discourse leaves no room for any reply" (Debord 1990, p. 29) is to ignore the doxa-like relations between image makers and spectators that comprise specific "specular regimes" (Metz 1982, Part III) or the democratic ideal of "collective looking" that J ohn Hartley (1992, p. 36) observes in our time. ${ }^{6}$ 
63 Many rhetorical dynamics of sentimental images in American politics prove respectable. Attending to these as well as the dubious or outright destructive uses of visual sentiment is one good way to enrich rhetoric as a situated theory of situated discourse. When advocates of hermeneutics, deconstruction, or other postmodern discourses scorn all television for the sheer use of emotive images, these commentators repeat in practice the rationalism and logocentrism that they scorn in theory. When rhetoricians appreciate postmodern attacks on general theories as important problems and tools for situated rhetoric, the prospects for learning about our visual politics of sentiment can expand.

\section{Ethicality}

64 We come in the end to the matter that started Adam Smith down the path of morals and sentimentality: sentimental discourses can induce moral outcomes. Sentimental images, including television images, are no exception; and their political uses are easy to spot: good as well as bad. Many agree with Hart, of course, that imaged emotionality charms citizens and seduces America, as his title puts it. Hart on the televised politician luring citizens to political positions is much like Plato on Ion as epitome of the rhapsode's art: "for I look down upon them from the stage, and behold the various emotions of pity, wonder, sternness, stamped upon their countenances when I am speaking: and I am obliged to attend to them; for unless I make them cry, I myself shall not laugh; and if I make them laugh, I shall do anything but laugh myself when the hour of payment arrives" (1936, p. 289).

65 To Plato, Ion as the seductive rhapsode was but a link - a magnet, Plato called him - in a chain that ran from the gods to Homer to the rhapsode to the listener. The chain was constructed "by divine inspiration and by possession" (p. 290). It deserved worry because "he who has no knowledge of a particular art will have no right judgment of the sayings and doings of that art" (p. 292). Neither the rhapsode nor the listener knows the truth about what the poet writes. In parallel fashion, neither the charming politician nor the seduced citizen knows the truth about what the politician makes: ads, buttons, videos, speeches, pamphlets, billboards, radio addresses, and all of the other political communications that bombard us, especially during campaigns.

66 Can these arts be ethical? Were Plato in his epistemic fit and Tertullian in his religious disdain correct? Of course, if the ancient Greek and the early Christian are right to take emotions as tools of 
anti-rationality, we must be ever on guard against our sentiments. We may suppose that action without thought for rationales or consequents can lead to equivalents of the Holocaust in Nazi Germany, the bombing in Oklahoma City, attacks on abortion clinics, outrages of ethnic cleansing, or terrorist assaults on the architecture of finance and war as on 9/11/01. But we may not suppose that actual perpetrators have lacked all logic or foresight, as though rationality could guarantee morality or preclude atrocity. Nor may we assume that action mindful of sentiment is bound to be perverse. We are not smart even to stipulate that it tends to be bad.

67 In assessing the sentimentalization of the political, we do well to avoid argumentum in extremis. The lethargic can be stirred from political inactivity to political activity by sentimental appeal. This can be good, bad, or indifferent, depending on particulars of the situation that need further investigation. The sort of situational projection that Smith found in sympathy can provide good foundations for political identity, or bad, but it is hard to see how many needed parts of politics could arise sans sentiment. Detachment, ignorance, obsolescence, inertness, and impotence are not the only or the inevitable results of imaged feelings; political engagement can be as much a positive result of sentimental discourses as political apathy can be a negative effect of them.

68 The argument here depends on understanding ethics in a premodern sense, as Aristotle understood ethos. Sentimental images on television or computer screens can link individuals sympathetically with virtual publics of other people. In the classical sense, this gives sentimental images ethical power. The sentimental can join the reasonable and the characterological in our experiences of television. To appreciate this is to restore pathos to its rightful place, with logos and ethos, as part of the trilogy of proofs that foster new identities and enable judicious public action. So long as we remember that the image's "aesthetic lightness does not absolve us from mortal gravity," but instead brings with it always an "ethical burden" (Peters 1997, p. 26), that judiciousness is an integral aspect of our spectatorship. We can profit more politically from vision-sensitive knowing and feelingdriven action than we must lose to them.

(c) Bruce E. Gronbeck, 2005. 


\section{References}

Baier, A. C. 1991. A Progress of Sentiments. Cambridge, MA: Harvard University Press.

Baudrillard, J. 1983. In the Shadow of the Silent Majorities, P. Foss, J. J ohnston, and P. Patton, trs. New York: Semiotext(e).

Baudrillard, J . 1988. The Ecstasy of Communication, S. Lotringer, ed., B. and C. Schutze, trs. NewYork: Semiotext(e), (1987).

Becker, S. L., and E. W. Lower. 1979. "Broadcasting in Presidential Campaigns." In The Great Debates, S. Kraus, ed. Bloomington: Indiana University Press, pp. 22-55.

Black, E. 1978. "The Sentimental Style as Escapism, or the Devil with Dan'l Webster." In Form and Genre, K. K. Campbell and K. H. J amieson, eds. Washington: National Communication Association, pp. 75-86.

Burke, E. 1963. "Conciliation with America." In Select British Eloquence, C. A. Goodrich, ed. Indianapolis: Bobbs-Merrill, (1852), pp. 265-291.

Cicero, Marcus Tulius. 1952. Brutus; Orator, G. L. Hendrickson and H. M. Hubbell, trs. Cambridge, MA: Harvard University Press.

Cooley, C. H. 1956. Human Nature and the Social Order. New York: Free Press, (1902).

Debord, G. 1983. Society of the Spectacle. Detroit: Black and Red, (1967).

Debord, G. 1990. Comments on Society of the Spectacle, M. Imrie, tr. New York: Verso, 1988).

Deleuze, G. 1991. Empiricism and Subjectivity. New York: Columbia University Press.

Denzin, N. K. 1992. Symbolic Interactionism and Cultural Studies. Cambridge, MA: Blackwell. 
Derrida, J . 1993. “The Rhetoric of Drugs.” Differences: AJ ournal of Feminist Cultural Studies, 5, 1, pp. 1-25.

Ewen, S. 1996. PR! A Social History of Spin. New York: Basic Books.

Fielding, R. 1972. The American Newsreel: 1911-1967. Norman: University of Oklahoma Press.

Fiske, J. 1989. Television Culture. New York: Methuen.

Gaonkar, D. P. 1999. "Rhetoric and Its Double: Reflections on the Rhetorical Turn in the Human Sciences." In Contemporary Rhetorical Theory, J. L. Lucaites, C. M. Condit, and S. Caudill, eds. New York: Guilford, (1990), pp. 194-212.

Gidal, T. 1973. Modern Photojournalism, 1910-1933. New York: Macmillan.

Gronbeck, B. E. 1993. "The Spoken and the Seen: The Phonocentric and Ocularcentricd Dimensions of Rhetorical Discourse." In Rhetorical Memory and Delivery: Classical Concepts for Contemporary Composition and Communication, ed. J.F. Reynolds. Hillsdale, NJ : Lawrence Erlbaum Associates, pp. 141-157.

Gronbeck, B. E. 1995. “Unstated Propositions: Relationships Among Verbal, Visual, and Acoustic Languages.” In Argumentation and Values, ed. S. J ackson. Washington, DC: National Communication Association, pp. 539-542.

Gronbeck, B.E. 1999. Paradigms of Speech Communication Studies: Looking Back Toward the Future. Monograph publication of the 1998 Carroll C. Arnold lecture, National Communication Association. Boston: Allyn \& Bacon.

Gronbeck, B.E. 2005. "Musings on the Emptiness and Dreariness of Postmodern Critique." http:// www.uiowa. edu/commstud/ faculty/ gronbeck/musings.html.

Hardie, M. 1920. War Posters Issued by Belligerent and Neutral Countries 1914-1919. London: A. and C. Black.

Hart, R. P. 1999. Seducing America. New York: St. Martin's Press, revised edition. 
Hartley, J. 1992. The Politics of Pictures. New York: Routledge.

Havelock, E. A. 1963. Preface to Plato. Cambridge, MA: Belknap Press.

Homer. 1990. The Iliad, B. Knox, ed., R. Fagles, tr. New York: Viking Penguin.

Hume, D. 1975a. Enquiries Concerning Human Understanding and Concerning the Principles of Morals, P.H.Nidditch, ed. Oxford: Clarendon Press, (1748/ 1751).

Hume, D. 1975b. A Treatise of Human Nature. L. A. Selby-Bigge, ed. Oxford: Clarendon Press, (1739-1740).

Jamieson, K. H. 1992. Dirty Politics. New York: Oxford University Press.

Jay, M. 1994. Downcast Eyes: The Denigration of Vision in Twentieth-Century French Thought. Berkeley: University of California Press.

Lasswell, H.D. 1971. Propaganda Technique in World War I. Cambridge, MA: MIT Press (1927).

Lyotard, J -F. 1984. The Postmodern Condition, G. Bennington and B. Massumi, trs. Minneapolis: University of Minnesota Press, (1979).

MacCann, R. D. 1973. The People's Films. New York: Hastings House.

MoGee, M. C. 1990. "Text, Context, and the Fragmentation of Contemporary Culture." Western J ournal of Communication, 54, pp. 274-289.

McKerrow, R. E. 1989. "Critical Rhetoric: Theory and Practice." Communication Monographs, 56, pp. 91-111.

Mead, G. H. 1934. Mind, Self, and Society. Chicago: University of Chicago Press.

Messaris, P. 1994. Visual Literacy. Boulder, CO: Westview Press. 
Metz, C. 1982. The Imaginary Signfier: Psychoanalysis and the Cinema. C. Britton, A. Williams, B. Brandster, and A. Guzzetti, trs. Bloomington: Indiana University Press.

Miller, A. H. 1994. "Social Groups as Symbols in America's Sense of Democratic Consensus." In Presidential Campaigns and American Self Images, A. H. Miller and B. E. Gronbeck, eds. Boulder, CO: Westview Press, pp. 190-213.

Morreale, J. 1993. The Presidential Campaign Film. Westport, CT: Praeger.

Nussbaum, M. C. 1995. Poetic J ustice. Boston: Beacon Press.

Osborn, M. 1986. "Rhetorical Depiction.” In Form, Genre, and the Study of Political Discourse, H. W. Simons and A. A. Aghazarian, eds. Columbia: University of South Carolina Press, pp. 79-107.

Peters, J . D. 1997. “Beauty's Veils: The Ambivalent Iconoclasm of Kierkegaard and Benjamin." In The Image in Dispute, D. Andrew, ed. Austin: University of Texas Press, pp. 9-32

Plato. 1936. The Works of Plato. B. J owett, tr. NewYork: Tudor.

Postman, N. 1992. Technopoly. New York: Knopf.

Schwartz, T. 1973. The Responsive Chord. Garden City, NY: Doubleday.

Shafesbury, Third Earl (Anthony Ashley Cooper). 1999. Characteristics of Men, Manners, Opinions, Times, Klein, L. E., ed. Cambridge: Cambridge University Press.

Sider, R. D. 1971. Ancient Rhetoric and the Art of Tertullian. London: Oxford University Press.

Smith, A. 1976. The Theory of Moral Sentiments, D. D. Raphael and A. L. MacFie, eds. Oxford: Clarendon Press (1759).

Sproule, J. M. 1997. Propaganda and Democracy. Cambridge: Cambridge University Press.

Stafford, B. M. 1996. Good Looking: Essays on the Virtue of Images. Cambridge, MA: MTT Press. 
Weaver, R. M. 1953. "The Spaciousness of Old Rhetoric." In The Ethics of Rhetoric. Chicago: Henry Regnery, pp. 164-185.

\section{Notes}

1 Adam Smith was appointed to the Chair of Logic at the University of Glasgow in 1751, moving to the Chair of Moral Philosophy the next year. There he lectured on natural theology and ethics as topics to precede the lectures on law and government. Essentially he was adapting perspectives and examples from his earlier lectures on rhetoric and belles lettres, which he had delivered in Edinburgh, 1748-50. It presumably was his peculiar but most interesting combination of political and literary principles that made his conceptions of political and economic theory, under the heading jurisprudence and civic law, so attractive. See the introduction to Raphael and MacFie's edition of The Theory of Moral Sentiments (1976). References here to that work are by section or page within the text.

2 See Shaftesbury's treatise on Sensus Communis reprinted in 1999, pp. 29-69, original publication in 1709, reprinted in his assembled essays as a part of Characteristics of Men, Manners, Opinions, Times, 1711.

3 Smith's discussion of the mirror or looking-glass produces an understanding of self quite similar to Charles Horton Cooley's (1956) theory of the mirrored self (see Denzin 1992, p. 4). If Smith has any currency in American social thought, it may well be because he can be considered one of the precursors to symbolic interactionism.

4 Technically the word comes from the Greek patriôtikós - a citizen whose political agenda were driven by a professed love of country. "Patriot" in that sense became popular in the eighteenth century, and even fell into disfavor among English- and Frenchspeaking peoples because of its association with disruptive political connections (the "Young Patriots" of Great Britain) and revolution in France. It was not unlike our use of "super-patriot" as a designation today.

5 When I show these video clips in foreign countries, I often get very different reactions. When I show Reagan's 1984 convention film, for example, its patriotic tributes simply do not move the viewers. They have no particular civic memories of the invasion of Normandy, the demilitarized zone between the Koreas, the 
camouflage uniforms of the Grenada soldiers, or Lee Greenwood's intoning of "God bless the U.S.A." over a montage of stereotyped American scenes. Evocation does not work without memories or echoes.

6 I am liberating the idea of specular regime from Metz's psychoanalytic study of cinema, and more particularly from his understanding of the cinematic experience as a waking-dreaming state that allows for special kinds of interplays between reality and visual discourse. The idea of regime is useful in a social sense, so that specular regimes reference learned modes of displaying and interpreting signs. 